\title{
Adenovirus infection in adults: reactive response of polymorphonuclear neutrophilic leukocytes study
}

\author{
V. D. Moskaliuk, I. V. Balaniuk, A. S. Sydorchuk, Kh. I. Vozna, M. O. Andruschak, I. V. Rudan
}

Higher State Educational Establishment of Ukraine "Bukovinian State Medical University”, Chernivtsi

The role of adenovirus infection in the SARS is significant but every year this group of infections makes up to $30 \%$ of general infectious morbidity. Nowadays features of nonspecific immune defence in patients with adenovirus infection are insufficiently studied. Particularly acute AVI problem appears to clinicians and scientists as a contagious disease, which is rapidly spreading in organized collectives, among military personnel, students.

Purpose. To study the reactive response of polymorphonuclear granulocytes in the peripheral blood of adult patients with adenovirus infection.

Materials and methods. 37 volunteers with SARS signs (Unified Protocol Criteria) were involved in this "case - control" type study. Absolute and relative quantities of the main immune cells populations in the peripheral blood were analyzed. Immunohematological indicators which characterize reactive response of the main non-specific immune cells were calculated. Clinical diagnosis was confirmed by the serological method of complement fixation test in paired sera and using adenoviruses common soluble complement-fixing antigen.

Results. Neutrophil granulocytes reactivity increased by $83.92 \%$ indicating these cells activation by cytokine system. The inflammatory process is accompanied by an increase in leukocytes absolute count $-19.76 \%$, band neutrophil leukocytes - in 2.18 times; lymphocytes $-30.30 \%$ and monocytes $-48.15 \%$.

Conclusions. Aforementioned means that there are different types of immune response to adenovirus infection antigens. Patients immune reactivity decreasing by $14.86 \%$ means that specific immune response is formed later. Method of neutrophils reactive response evaluation can be used by practicing doctors for the early prediction of possible anti-infectious protection system alteration.

\section{Аденовірусна інфекція в дорослих: дослідження реактивної відповіді поліморфноядерних нейтрофіньних гранулоцитів}

\section{В. А. Москалюк, І. В. Баланюк, А. С. Сидорчук, Х. І. Возна, М. О. Андрущак, І. В. Рудан}

Частка аденовірусної хвороби у структурі ГРВІ є істотною, а ця група інфекцій щороку становить до 30 \% від загальної інфекційної морбідності. Недостатньо вивчено особливості неспецифічного протиінфекційного захисту у хворих на аденовірусну інфекцію (АВI). Особливо гостро проблема АВІ постає перед клініцистами, науковцями як контагіозна хвороба, що швидко поширюється в організованих колективах (серед військовослужбовців, студентства).

Мета роботи - вивчити реактивну відповідь поліморфноядерних гранулоцитів периферичної крові дорослих хворих на АВІ.

Матеріали та методи. У дослідження типу «випадок - контроль» за добровільною згодою залучили 37 осіб молодого віку з ознаками гострої респіраторної вірусної інфекції на момент звернення за медичною допомогою (за критеріями Уніфікованого протоколу). Аналізували абсолютну й відносну кількість основних популяцій імунокомпетентних клітин периферичної крові, розрахували імуногематологічні показники, що характеризують реактивну відповідь основних клітин неспецифічного імунітету. Клінічний діагноз підтверджували серологічним методом у реакції зв'язування комплементу з парними сироватками та використанням загального розчинного комплементфіксуючого антигена аденовірусів.

Результати. Встановили зростання реактивності нейтрофільних гранулоцитів на 83,92 \%, що вказує на активацію цих клітин системою цитокінів. Запальний процес супроводжується збільшенням абсолютної кількості лейкоцитів на 19,76 \%, паличкоядерних нейтрофрільних лейкоцитів - у 2,18 раза; лімфоцитів - на $30,30 \%$, моноцитів - на 48,15 \%. Виявили зростання реактивності нейтрофільних гранулоцитів на 83,92 \%, що вказує на активацію цих клітин системою цитокінів у неспецифрічному протиінфекційному захисті, а тому його загальна активність збільшується на 12,62 \%.

Висновки. Наведене $є$ свідченням формування різних типів імунної відповіді на аденовірусні антигени. Специфічна імунна відповідь формується пізніше, що підтверджується зниженням індексу імунологічної реактивності організму хворих на 14,86 \%. Методику оцінювання реактивної відповіді нейтрофілів можна використовувати у практичній роботі лікарів для раннього прогнозування можливих зрушень у системі протиінфекційного захисту організму хворих.
Key words: adenovirus infections, cellular reactivity, neutrophils, active immune response.

Zaporozhye medical journal 2018; 20 (3), 339-343 DOI: 10.14739/2310-1210. 2018.3.132123

E-mail: balanyk85@gmail.com

Ключові слова: аденовірусні інфекції, киітинна віАповіАь, нейтрофіли периферичної крові, імунна віАповіАь.

Запорізький медичний журнал. - 2018. T. 20, № 3(108). C. 339-343

\section{Аденовирусная инфекция у взрослых: исследование реактивного ответа полиморфноядерных нейтрофилов}

\section{В. А. Москалюк, И. В. Баланюк, А. С. Сидорчук, К. И. Возная, М. А. Андрущак, И. В. Рудан}

Доля аденовирусной болезни в структуре ОРВИ существенна, и эта группа инфекций ежегодно составляет до 30 \% от общей инфекционной морбидности. Недостаточно изучены особенности неспецифической противоинфекционной защиты у больных аденовирусной инфекцией (АВИ). Особенно остро проблема АВИ предстает перед клиницистами и учеными как контагиозная болезнь, которая приобретает быстрое распространение в организованных коллективах (среди военнослужащих, студенчества). 
Ключевые слова: аденовирусные инфекции, клеточный ответ, нейтрофилы периферической крови, иммунный ответ.

Запорожский медицинский журнах. - 2018. T. 20, № 3(108). C. 339-343

Цель работы - изучить клеточный ответ полиморфноядерных гранулоцитов периферической крови взрослых больных АВИ. Материалы и методы. В исследование типа «случай-контроль» по добровольному согласию привлечены 37 лиц молодого возраста с признаками острой респираторной вирусной инфекции на момент обращения за медицинской помощью (по критериям Унифицированного протокола). Анализировали абсолютное и относительное количество основных популяций иммунокомпетентных клеток периферической крови, проводили расчет иммуногематологических показателей, характеризующих реактивный ответ основных клеток неспецифического иммунитета. Клинический диагноз подтверждали серологическим методом в реакции связывания комплемента с парными сыворотками и использованием общего растворимого комплементфиксирующего антигена аденовирусов.

Результаты. Установлен рост реактивности нейтрофилов на 83,92 \%, что указывает на активацию этих клеток системой цитокинов. Воспалительный процесс сопровождается ростом абсолютного количества лейкоцитов на 19,76 \%, палочкоядерных нейтрофильных лейкоцитов - в 2,18 раза; лимфоцитов - на 30,30 \%, моноцитов - на 48,15 \%. Установлен рост реактивности нейтрофилов на 83,92 \%, что указывает на активацию этих клеток системой цитокинов в неспецифической противоинфекционной защите, а потому его общая активность возрастает на 12,62 \%.

Выводы. Указанное свидетельствует о формировании различных типов иммунного ответа на аденовирусные антигены. Специфический иммунный ответ формируется позже, что подтверждается снижением индекса иммунологической реактивности организма больных $14,86 \%$. Методику оценки реактивного ответа нейтрофилов можно использовать в практической работе врачей для раннего прогнозирования возможных сдвигов в системе противоинфекционной защиты организма больных.

\section{Background}

According to official statistics last year in Ukraine about 5.5 million cases of acute respiratory viral infections were registered in the epidemic season. Adenovirus infection (AVI) ranges among the first "five" in the human diseases structure of acute respiratory viral infections, by the prevalence among various populations and clinical outcomes [1].

$\mathrm{AVI}$ is a challenge to the clinicians and scientists in view of disease contagiousness and rapid spread in organized groups, including soldiers and students [6]. Adenoviruses are a cause of the sporadic as well as epidemic morbidity and consequently - significant financial losses through disability $[5,7]$.

Adenovirus recognized as an agent of various syndromes and clinical forms: pharyngoconjunctival fever, gastroenteritis, hemorrhagic cystitis, virus-associated pneumonia, mesadenitis; adenoviruses carcinogenicity has been proved $[7,8]$.

Adenoviruses cause both innate and adaptive immune responses. Recovery after adenovirus infection is associated with the sulphur-containing type-specific virusneutralizing antibody response. Cell-mediated immunity is essential for host defense against many viruses, including adenoviruses. Fatal AVI mostly develop in immunodeficient patients, particularly with defects in cellular immunity $[2,5]$.

The basis of nonspecific immune defense (non-specific resistance) of the human body is polymorphonuclear neutrophil granulocytes. This functional cell plays an active role in the inflammation and at all stages of the immune response. Processes which regulate cellular (phagocytosis) and humoral factors of human nonspecific reactivity can be identified. Phagocytosis is ensured by two populations of cells - leukocytes mononuclear and polynuclear granulocytes (PNG). The last ones are the first line of defense against the penetration into the body various bacteria, viruses, fungi.

PNG functional activity is subjected to a large number of membrane receptors, soluble and corpuscular activators. This provides a regular activity aimed at capture, destruction and elimination of microorganisms. Neutrophils influenced by chemoattractants migrate to the site of infection and completely eliminates it via phagocytosis. High concentration of PNG leads to self-activation, as a result of which the cells actively interact and create special centers of infiltration in the tissue [2].

Our studies on polymorphonuclear granulocytes reactive response determination in the peripheral blood of patients with $A B I$ contribute to the modern ideas about immunopathogenesis of the disease extension, and thus the results can be taken into account in a diagnostic algorithm formulation and treatment regimens of this infectious disease.

\section{The aim}

To study the reactive response of polymorphonuclear granulocytes in peripheral blood of patients with upper respiratory tract adenoviral infection.

\section{Materials and methods}

In this prospective clinical study of the "case-control", which was conducted from September 2014 to March 2015 at Chernivtsi Municipal Polyclinic N 5 (Head Physician L. V. Klichuk), 37 young people were selected from among volunteers: 22 women and 15 male (from 17 to 24 years old, mean age was $22.18 \pm 1.78$ years) with symptoms of acute respiratory viral infections when medical help-seeking (the Unified Protocol criteria) [4]. Paraclinical examination was performed within the first $24-48$ hours of illness. The control group consisted of 32 practically healthy people, the average age was $22.14 \pm 1.37$ years. Studied groups were comparable in gender and age.

Clinical diagnosis was confirmed by the serological method of complement fixation test in paired sera and using adenoviruses common soluble complement-fixing antigen.

We analyzed an absolute and relative number of immune cells main populations in peripheral blood, the calculation of immuno-hematological parameters that characterize the reactive response of nonspecific immunity main cells was performed. Data of the peripheral blood count were determined by the hematology analyzer in the clinical laboratory of polyclinic institution. For blood samples analysis the blood was drawn from patients and 
Table 1. The absolute and relative number of immune cells main populations in the peripheral blood of patients with the upper respiratory tract adenoviral infection, $\mathrm{M} \pm \mathrm{m}$

\begin{tabular}{|c|c|c|c|c|c|}
\hline Immunocompetent calls & Units of measure & $\begin{array}{l}\text { Patients with AVI } \\
(n=37)\end{array}$ & $\begin{array}{l}\text { Practically healthy persons } \\
(n=32)\end{array}$ & $\begin{array}{l}\text { Immune dysfunction } \\
\text { degree }\end{array}$ & $\mathbf{P}$ \\
\hline Leucocytes & $\times 10^{9} / 1$ & $7.03 \pm 0.29$ & $5.87 \pm 0.31$ & +1 & $<0.05$ \\
\hline \multirow[t]{2}{*}{ Granulocytes } & $\%$ & $60.77 \pm 1.77$ & $59.91 \pm 2.54$ & +1 & $>0.05$ \\
\hline & $\times 10^{9} / 1$ & $4.27 \pm 0.44$ & $3.52 \pm 0.34$ & +1 & $>0.05$ \\
\hline \multirow[t]{2}{*}{ Neutrophil Granulocytes } & $\%$ & $59.33 \pm 2.18$ & $58.22 \pm 3.16$ & +11 & $>0.05$ \\
\hline & $\times 10^{9} / 1$ & $4.17 \pm 0.42$ & $3.42 \pm 0.31$ & +1 & $>0.05$ \\
\hline \multirow[t]{2}{*}{ Segmented Neutrophils } & $\%$ & $52.44 \pm 1.42$ & $54.43 \pm 3.07$ & -1 & $>0.05$ \\
\hline & $\times 10^{9} / 1$ & $3.69 \pm 0.38$ & $3.20 \pm 0.29$ & +1 & $>0.05$ \\
\hline \multirow[t]{2}{*}{ Band Neutrophils } & $\%$ & $6.81 \pm 0.47$ & $3.79 \pm 0.57$ & +111 & $<0.05$ \\
\hline & $\times 10^{9} / 1$ & $0.48 \pm 0.05$ & $0.22 \pm 0.02$ & $+|l|$ & $<0.01$ \\
\hline Eosinophilic Leucocytes & $\%$ & $1.47 \pm 0.09$ & $1.69 \pm 0.11$ & -1 & $>0.05$ \\
\hline Basophilic Leucocytes & $\%$ & 1.0 & 0 & - & - \\
\hline \multirow[t]{2}{*}{ Agranulocytes } & $\%$ & $42.47 \pm 1.12$ & $38,38 \pm 1,07$ & +1 & $>0.05$ \\
\hline & $\times 10^{9} / 1$ & $2.99 \pm 0.30$ & $2.25 \pm 0.21$ & +1 & $<0.05$ \\
\hline \multirow[t]{2}{*}{ Lymphocytes } & $\%$ & $36.73 \pm 1.64$ & $33.75 \pm 1.33$ & +1 & $>0.05$ \\
\hline & $\times 10^{9} / 1$ & $2.58 \pm 0.24$ & $1.98 \pm 0.20$ & +1 & $<0.05$ \\
\hline \multirow[t]{2}{*}{ Monocytes } & $\%$ & $5.74 \pm 0.30$ & $4.63 \pm 0.38$ & +1 & $>0.05$ \\
\hline & $\times 10^{9} / 1$ & $0.40 \pm 0.03$ & $0.27 \pm 0.03$ & +11 & $<0.05$ \\
\hline Erythrocytes & $\times 10^{12} / 1$ & $3.87 \pm 0.38$ & $4.03 \pm 0.41$ & -1 & $>0.05$ \\
\hline Erythrocyte sedimentation rate & $\mathrm{mm} /$ year & $6.11 \pm 0.12$ & $4.31 \pm 0.26$ & +11 & $<0.01$ \\
\hline
\end{tabular}

apparently healthy people, then it was mixed in a clean test tube with an anticoagulant to prevent platelet aggregation, to preserve the structure of leukocytes, monocytes / macrophages and erythrocytes. The absolute and relative number of immune cells main populations counting was performed according to the automated hematology analyzer series NV instructions. The immune indexes and rates were calculated by the methods described in the previous papers $[3,4]$.

The data results were processed using the MyStat 12 statistical software (USA). The data reliability of independent samples was calculated by t-test Student (in the close to normal distribution), statistical significance was defined as a p value $<0.05$.

\section{Results}

Considering immunopathogenesis of $\mathrm{AVI}$ we note that monocytes / macrophages, T-cells and neutrophils that produce cytokines are involved in response to the viral entry. The immune response to the initiation stage primarily consists of non-specific reactivity mechanisms. The prognosis for the early stages of infection and inflammation course depends on the state of non-specific protective and adaptive mechanisms. So, the system of organism non-specific resistance involves neutrophils, monocytes I macrophages and other immunocompetent cells. We present hemogram parameters of studied patients groups according to the chosen design of epidemiological studies (Table 1).

To ascertain the informative dynamic changes in reactive response of polymorphonuclear granulocytes in the peripheral blood of enrolled patients, the degree of each indicator immune dysfunction was determined, from the values of absolute and relative number of immune cells main populations to the neutrophil phagocytosis determination.

The analysis of hemograms had been demonstrated a tendency to the first degree immune shifts in 13 indicators
$(17.22 \%)$, the second degree of increase in activity was observed in 3 indicators (16.67\%), and the growth of the absolute and relative number of band neutrophils showed the third degree of immune dysfunction. The inflammatory process was accompanied by increase in the leukocytes absolute number by $19.76 \%$, band neutrophils - 2.18 times; lymphocytes - by $30.30 \%$ and monocytes - by $48.15 \%$. The above mentioned is an evidence of immune response different types to adenoviral antigens which is accompanied clinically by manifestation of intoxication and catarrhal infectious inflammation.

There was a tendency to increase in relative number of granulocytes (by $1.44 \%$ ), as well as agranulocytes by $10.66 \%$, that confirms the activation of organism nonspecific and specific immune defense factors and mechanisms of the basic group young people.

Study of phagocytosis has important clinical and immunological significance that is the complex analysis and design of the non-specific reactivity competence and diagnosis of immunodeficiency states. Analysis of phagocytosis and neutrophils reactive responses facilitates a diagnosis of secondary immunodeficiency caused by intracellular pathogens (viruses, chlamydia, mycoplasma). Incomplete information about the polymorphonuclear neutrophils role in the human immune defense is given in the available literature, challenging us to keep studying the PNG reactive response of young people with $A B I$, in particular on the basis of the imunohematologic indicators (Table 2).

The studies results indicate a significant shift of neutrophils by $85.71 \%$, an increase of the leukocytes ratio and ESR by $72.0 \%$, which evidences the presence of intoxication pathogenetically caused by the destruction of adenovirusesinfected cells. The increase in reactivity of neutrophils to $83.92 \%$ indicates the cytokine system of these cells activation in nonspecific immune defense and therefore its overall activity increases by $12.62 \%$. The above mentioned statements confirm an important role of non-specific protection 
Table 2. Reactive response of peripheral blood neutrophils in the patients with mild and moderate adenovirus infection, $\mathrm{M} \pm \mathrm{m}$

\begin{tabular}{|c|c|c|c|c|}
\hline Immunohematological indicators & Patients with AVI ( $n=37$ ) & Control group $(n=32)$ & Immune dysfunction degree & $\mathbf{P}$ \\
\hline Reactive response ratio of neutrophils & $5.72 \pm 0.24$ & $3.11 \pm 0.17$ & $+|l|$ & $<0.01$ \\
\hline Neutrophilic-lymphocytic ratio & $1.62 \pm 0.15$ & $1.72 \pm 0.17$ & -1 & $>0.05$ \\
\hline Index of neutrophils shift & $0.13 \pm 0.02$ & $0.07 \pm 0.01$ & $+|l|$ & $<0.05$ \\
\hline Index of leukocytes shift & $1.43 \pm 0.11$ & $1.56 \pm 0.12$ & -1 & $>0.05$ \\
\hline Lymphocytic-granulocytic ratio & $6.04 \pm 0.31$ & $5.63 \pm 0.27$ & +1 & $>0.05$ \\
\hline Neutrophils-monocytes ratio & $10.34 \pm 0.37$ & $12.57 \pm 0.42$ & -1 & $<0.05$ \\
\hline Leukocyte ratio and ESR & $0.43 \pm 0.04$ & $0.25 \pm 0.02$ & $+|l|$ & $<0.05$ \\
\hline Leukocytes index & $1.26 \pm 0.10$ & $1.20 \pm 0.11$ & +1 & $>0.05$ \\
\hline Lymphocytes index & $0.62 \pm 0.05$ & $0.58 \pm 0.05$ & +1 & $>0.05$ \\
\hline The index of non-specific reactivity & $70.04 \pm 1.09$ & $62.19 \pm 0.97$ & +1 & $>0.05$ \\
\hline Immunological reactivity ratio & $6.66 \pm 0.12$ & $7.65 \pm 0.14$ & -1 & $<0.01$ \\
\hline Index of organism resistance & $70.04 \pm 1.09$ & $62.01 \pm 0.87$ & +1 & $<0.01$ \\
\hline
\end{tabular}

Table 3. The phagocytic activity of polymorphonuclear neutrophils in peripheral blood of young patients with mild and moderate adenovirus infection, $\mathrm{M} \pm \mathrm{m}$

\begin{tabular}{|c|c|c|c|c|}
\hline Indexes & Units of measure & Patients with AVI ( $n=37$ ) & Practically healthy persons $(n=32$ ) & $\mathbf{P}$ \\
\hline Phagocytic activity & $\%$ & $62.29 \pm 1.87$ & $72.23 \pm 2.57$ & $<0.05$ \\
\hline Phagocytic number & Unit & $5.09 \pm 0.17$ & $7.17 \pm 0.19$ & $<0.01$ \\
\hline Phagocytic capacity of blood & $\times 10^{9} / 1$ & $21.23 \pm 0.37$ & $24.52 \pm 0.48$ & $<0.01$ \\
\hline Active PNG & $\times 10^{9} / 1$ & $2.60 \pm 0.22$ & $2.47 \pm 0.21$ & $>0.05$ \\
\hline NST-spontaneous & $\%$ & $8.47 \pm 0.09$ & $9.37 \pm 0.10$ & $<0.01$ \\
\hline NST-activated & $\%$ & $37.41 \pm 0.31$ & $42.78 \pm 0.24$ & $<0.001$ \\
\hline Potential bactericidal activity & $\%$ & $28.94 \pm 0.42$ & $33.41 \pm 0.34$ & $<0.01$ \\
\hline Phagocytosis activity coefficient & Relative units & $4.42 \pm 0.05$ & $4.57 \pm 0.07$ & $>0.05$ \\
\hline
\end{tabular}

in the formation of adenoviruses-induced antiviral protection on the first stage. The specific immune response is formed later, as evidenced by the decrease in the index of immunological reactivity in patients with $\mathrm{AVI}$ to $14.86 \%$. This is also reflected in the downward trend in leukocyte index shift by $9.09 \%$ and index of neutrophils to monocytes ratio - by $21.57 \%$.

A reactive answer of these important cells is shown in protective and secretory functions. Examining the function of PNG, it is expedient to mention that each of these cells, under the influence of a signal from a certain cytokine, is able to migrate to the viral entry focus in a single direction, the ultimate goal of which is phagocytosis. The results of the PNG phagocytic activity state in peripheral blood of patients with $\mathrm{AVI}$ are shown in the Table 3.

\section{Discussion}

In young people with mild to moderate AVI course phagocytic activity of polymorphonuclear neutrophils decreased by $15.96 \%$. This constitutes a violation of the normal phagocytosis processes in the early stages, which probably correlates with humoral factors of nonspecific protection the complement system activity, immunoglobulins, adhesins, opsonins; so phagocytic capacity of blood is reduced by $15.50 \%$. A tendency to increase in the total count of PNG by $5.26 \%$ is observed, indicating the compensatory functions activation.

Impairment of PNG phagocytic activity is also found at the final stages of phagocytosis: spontaneous NST-reduced by $10.63 \%$, which proves a viral infection presence. The functional reserve of phagocytes oxygen-dependent bactericidal mechanisms reduction by $15.45 \%$ is also observed; a reducing trend of phagocytic activity is noted.

\section{Conclusions}

1. The course of acute adenoviral infection with a clinically predominant lesion of the upper respiratory tract from mild to moderate severity in young people is accompanied by the neutrophils reactive response activation as the first-line of non-specific immune defense cell component.

2. The specific immune response in young people with $\mathrm{AVI}$ is formed later - on the 5-7th day from the infectious disease beginning, which is evidenced by a decrease in the immunological reactivity index and tendency to leukocytes and neutrophils to monocytes ratio reduction.

3. Functional activity of polymorphonuclear neutrophils in the peripheral blood of patients with adenoviral infection is changed both at the initial and final stages of phagocytosis, however phagocytic activity of these cells, according to our research, is maintained at a sufficient level.

Conflicts of Interest: authors have no conflict of interest to declare. Конфлікт інтересів: віАсутній.

\section{Information about authors:}

Moskaliuk V. D., MD, PhD, DSc, Professor of the Department of Internal Medicine and Infectious Diseases of HSEE of Ukraine "Bukovinian State medical University", Chernivtsi.

Balaniuk I. V., MD, PhD, Associate professor of the Department of Internal Medicine and Infectious Diseases of HSEE of Ukraine "Bukovinian State medical University", Chernivtsi.

Sydorchuk A. S., MD, PhD, Associate professor of the Department of Internal Medicine and Infectious Diseases of HSEE of Ukraine "Bukovinian State medical University", Chernivtsi.

Vozna Kh. I., MD, PhD, Assistant of the Department of Internal Medicine and Infectious Diseases of HSEE of Ukraine "Bukovinian State medical University", Chernivtsi. 
Andruschak M. O., MD, Assistant of the Department of Internal Medicine and Infectious Diseases of HSEE of Ukraine "Bukovinian State medical University", Chernivtsi.

Rudan I. V., MD, Assistant of the Department of Internal Medicine and Infectious Diseases of HSEE of Ukraine "Bukovinian State medical University", Chernivtsi.

\section{Відомості про авторів:}

Москалюк В. А., А-р меА. наук, професор каф. внутрішньої медицини та інфекційних хвороб, ВАНЗ “Буковинський Аержавний медичний університет", м. Чернівці, Україна.

Баланюк І. В., канА. меА. наук, асистент каф. внутрішньої меАицини та інфекційних хвороб, ВАНЗ “Буковинський Аержавний медичний університет", м. Чернівці, Україна. Сидорчук А. С., канА. меА. наук, Аоцент каф. внутрішньої меАицини та інфекційних хвороб, ВАНЗ “Буковинський Аержавний медичний університет", м. Чернівці, Україна. Возна X. І. канА. меА. наук, асистент каф. внутрішньої медицини та інфекційних хвороб, ВАНЗ “Буковинський державний медичний університет", м. Чернівці, Україна.

Андрущак М. О., асистент каф. внутрішньої меАицини та інфекційних хвороб, ВАНЗ “Буковинський Аержавний меАичний університет", м. Чернівці, Україна.

Рудан І. В., асистент каф. внутрішньої медицини та інфекційних хвороб, ВАНЗ «Буковинський Аержавний меАичний університет", м. Чернівці, Україна.

\section{Сведения об авторах:}

Москалюк В. А., А-р меА. наук, профессор каф. внутренней меАицины и инфекционных болезней, ВГУЗ “Буковинский государственный медицинский университет", г. Черновцы, Украина.

Баланюк И. В., канА. меА. наук, ассистент каф. внутренней меАицины и инфекционных болезней, ВГУЗ “Буковинский государственный медицинский университет", г. Черновцы, Украина.

Сидорчук А. С., канА. меА. наук, Аоцент каф. внутренней меАицины и инфекционных болезней, ВГУЗ “Буковинский государственный меАицинский университет", г. Черновцы, украина.

Возна К. И., канд. меА. наук, ассистент каф. внутренней медицины и инфекционных болезней, ВГУЗ «Буковинский государственный медицинский университет", г. Черновцы, Украина.

Андрущак М. О., ассистент каф. внутренней медицины и инфекционных болезней, ВГУЗ “Буковинский государственный медицинский университет", г. Черновцы, Украина.

Рудан И. В., ассистент каф. внутренней меАицины и инфекционных болезней, ВГУЗ “Буковинский государственный медицинский университет», г. Черновцы, Украина.

Надійшла Ао редакції / Received: 07.11.2017

Після Аоопрацювання / Revised: 14.11.2017

Прийнято Ао Аруку / Accepted: 29.11.2017

\section{References}

[1] (2015) Hryp ta HRVI v Ukraini [Influenza and acute respiratory viral infections in Ukraine]. Kyiv [in Ukrainian].

[2] Mal'cev, D. V., Kazmirchuk, V. E., Carik, V. V., Yashchenko, M. Yu., Plakhotnaya, D. V., \& Klimchuk, V. V. (2012) Immunodeficitnye bolezni cheloveka [Immunodeficiency diseases of man]. Kyiv: Feniks. [in Russian].

[3] Sydorchuk, Y., Sydorchuk, L. I., Levytska, S. A., Kaspruk, N. A., Sydorchuk, R. I., Sydorchuk, L. P., \& Sydorchuk, A. S. (2015) Reaktyvna vidpovid neitrofilnykh hranulotsytiv peryferychnoi krovi khvorykh na hostryi bronkhit [Reactive response of neutrophilic granulocytes of peripheral blood of patients with acute bronchitis]. Bukovynskyi medychnyi visnyk, 19(2), 172-176. [in Ukrainian].

[4] Speranskij, I. I., Samojlenko, G. E., \& Lobacheva, M. V. (2009) Obshiij analiz krovi - vse li ego vozmozhnosti ischerpany? Integral'nye indeksy intoksikacii kak kriterii ocenki tyazhesti techeniya e'ndogennoj intoksikacii, eyo oslozhnenij i e'ffektivnosti provodimogo lecheniya [The general or common analysis of a blood - whether all its possibilities are settled or exhausted? Integral indices of intoxication as criteria for assessing the severity of the course of endogenous intoxication, its complications and the effectiveness of the treatment]. Zdorov'e Ukrainy, 6(19), 51-57. [in Russian].

[5] (2014) Unifikovanyi klinichnyi protokol pervynnoi medychnoi dopomohy doroslym ta ditiam (UKPMD) «Hostri respiratorni infektsii» [Unified clinical protocol for primary care for adults and children (UKMPT) "Acute respiratory infections»]. Kyiv. [in Ukrainian].

[6] Tabain, I., Ljubin-Sternak, S., Čepin-Bogović, J., Markovinović, L., Knezović, I. \& Mlinarić-Galinović, G. (2012). Adenovirus Respiratory Infections in Hospitalized Children. The Pediatric Infectious Disease Journal, 31(7), 680-684. doi: 10.1097/INF.0b013e318256605e.

[7] Kajon, A., Moseley, J., Metzgar, D., Huong, H., Wadleigh, A., Ryan, M., \& Russell, K. (2007). Molecular Epidemiology of Adenovirus Type 4 Infections in US Military Recruits in the Postvaccination Era (1997-2003). The Journal of Infectious Diseases, 196(1), 67-75. doi: $10.1086 / 518442$

[8] Shah, K. (2006). SV40 and human cancer: A review of recent data. International Journal of Cancer, 120(2), 215-223. doi: 10.1002/jic.22425. 